D’une manière générale, le Catalogue est en bonne voie, sauf pour quelques zones qui se heurtent à d'importantes difficultés. De ce nombre sont la zone primitivement attribuée à Potsdam et reprise par Oxford et Hyderabad, et la partie de la zone de Perth dont Edimbourg a assumé les mesures et la publication. Une discussion s'engage sur les moyens d'aider ces observatoires à mener à bien leur entreprise. Ces moyens se raménent à l'attribution par l'Union de subventions destinées à couvrir les frais d'impressions. La discussion, à laquelle Sir Frank Dyson prend une grande part, aboutit au vœu suivant: "La Commission émet le vou que la subvention annuelle de $£ 300$ accordée par l'Assemblée Générale de I928 comme contribution aux frais d'impression du Catalogue photographique soit prolongée jusqu'à la Réunion suivante de l'Union."

Sur la proposition de Sir Frank Dyson, basée sur les conditions dans lesquelles se poursuivent les travaux dans les Observatoires de Hyderabad, Oxford et Edimbourg, la Commission décide que les sommes provenant des subventions de l'Union devront être employées dans l'ordre de préférence suivant: Hyderabad, Edimbourg, Oxford.

M. le Président appelle ensuite l'attention sur les Observatoires de Melbourne et de Sydney qui sont aux prises avec de grandes difficultés et qui, de plus, sont menacés d'être supprimés. Cette situation fait l'objet d'un échange de vues qui ne conduit à aucune conclusion en raison de l'incertitude de la situation.

M. Lagarde donne des indications sur l'état de la Carte qui est bien moins avancée que le Catalogue mais a été cependant l'objet d'importants travaux.

M. Baillaud fait ressortir le grand intérêt de la Carte qui a été, à l'origine, le principal but de l'entreprise et ne doit pas être négligée. Si on ne peut, pour le moment, l'exécuter au complet, on doit tout au moins exécuter la région de la Voie lactée qui est d'une importance toute particulière en ce qui concerne les études de statistique ayant pour objet la répartition des grandeurs stellaires et pour but la détermination de la forme de la Voie lactée dans l'espace. M. le Président indique que ce point de vue a déjà été signalé et que, notamment, il a fait l'objet d'une communication détaillée de $M$. Mineur à la réunion du Comité national français d'astronomie en juillet I93I.

En conclusion, sur la proposition de M. Baillaud, la Commission recommande aux observatoires engagés dans l'entreprise de ne pas abandonner la prise des clichés de la série de la Carte et de s'efforcer de les reproduire par l'héliogravure, tout au moins dans la région de la. Voie lactée.

\title{
Commission 24. (Stellar Parallaxes and Proper Motions.)
}

President: Prof. S. A. Mitchell.

SECRETARY: Prof. F. Slocum.

There were two meetings of the Commission. The first meeting was devoted to an informal discussion of programmes for parallax work. The second session was devoted to a discussion of systematic errors. The President gave a brief summary of the two latest determinations of the systematic errors of trigonometric parallaxes, by Schlesinger (parallaxes published to I924) and by van Maanen (parallaxes to I927). Both investigators had used the same basis of comparison, namely, the Mt Wilson spectroscopic parallaxes, and both had made the same fundamental assumption, namely, that the systematic errors of the spectroscopic parallaxes depending on right ascension were negligible. In carrying out the comparisons, the 
difference between the spectroscopic parallax (S) and the trigonometric (T) was found for each parallax measure. The results for each observatory doing trigonometric work were discussed separately. Means of the differences $\mathrm{S}-\mathrm{T}$ were formed for each of the 24 hours of right ascension. From these differences, by means of graphical methods or harmonic analysis, systematic corrections were found for each hour of right ascension for each observatory devoted to trigonometric parallaxes.

For zero-point, Schlesinger had adopted the mean of the trigonometric parallaxes, while van Maanen had taken the mean of the spectroscopic parallaxes. The difference for each trigonometric series between the results of Schlesinger and van Maanen is partly explained as due to difference in zero-point. The very great differences for some of the series cannot be explained by the larger amount of material used by van Maanen.

Through the kindness of van Maanen, Mitchell was furnished with the individual differences $\mathrm{S}-\mathrm{T}$ that had gone into van Maanen's discussion. These differences arranged in increasing order of right ascension were divided by Mitchell into two equal groups, the Ist, 3 rd, $5^{\text {th }}$ and all odd-numbered stars in one group, and the even-numbered stars in another. This was done for Allegheny and McCormick on account of their large number of stars. Following the methods of van Maanen, curves were found by harmonic analysis for the odd- and even-numbered stars separately. When these curves were exhibited at the meeting, it was agreed by all present that the large differences between the curves for the two groups of stars were the result primarily of accidental errors. In fact, there seemed little evidence of systematic errors. For the McCormick parallaxes, curves were found in similar manner where the large differences $S-T$ were omitted, and these curves showed periodic terms remarkably small in size. In practically all cases the large differences $\mathrm{S}-\mathrm{T}$ were from dwarf stars where the trigonometric parallaxes are considered to be more accurate than the spectroscopic.

Dr Schlesinger's announcement of a new Yale catalogue of parallaxes was received with much satisfaction. The catalogue will include all trigonometric parallaxes published before the end of r933. The members of the Commission unanimously agreed that the catalogue should include a discussion of systematic errors of the various trigonometric series and of the spectroscopic parallaxes as well. It was further suggested that the catalogue might give in parallel columns two values of the trigonometric parallax, namely, both before and after the application of systematic errors.

\section{Commission 25. (Photométrie Stellatre.)}

Acting President: M. Jules Baillaud.

Secretary: Miss Cecilia H. Payne.

The Committee expressed its appreciation of the value of the work done by Prof. Seares, while President of the Commission, in the direction of establishing the relations between various other catalogues and the International System.

The relations given by Prof. Seares, in the Draft Report, between the International System and the catalogues that have appeared during the last four years, form a new and very important contribution to this fundamental problem. But nothing in science can be definitive. The formulae given by Seares will be subject to modification by more extended discussion: they must be regarded as provisional; the Committee decided to place them in an appendix to the main report. 